NBER WORKING PAPER SERIES

\title{
MANAGERIAL INCENTIVES AND VALUE CREATION: EVIDENCE FROM PRIVATE EQUITY
}

\author{
Phillip Leslie \\ Paul Oyer \\ Working Paper 14331 \\ http://www.nber.org/papers/w14331 \\ NATIONAL BUREAU OF ECONOMIC RESEARCH \\ 1050 Massachusetts Avenue \\ Cambridge, MA 02138 \\ September 2008
}

We thank Ben Beder, Marco Beltran, Christopher Jung, William Vijverberg, and Alex Wong for research assistance, and thanks to Bengt Holmstrom and Steve Kaplan for helpful feedback. We are also very grateful to a number of executives at private equity firms for giving us insights into their business practices. The views expressed herein are those of the author(s) and do not necessarily reflect the views of the National Bureau of Economic Research.

NBER working papers are circulated for discussion and comment purposes. They have not been peerreviewed or been subject to the review by the NBER Board of Directors that accompanies official NBER publications.

(C) 2008 by Phillip Leslie and Paul Oyer. All rights reserved. Short sections of text, not to exceed two paragraphs, may be quoted without explicit permission provided that full credit, including $\odot$ notice, is given to the source. 
Managerial Incentives and Value Creation: Evidence from Private Equity

Phillip Leslie and Paul Oyer

NBER Working Paper No. 14331

September 2008

JEL No. G3,J33,L20,M52

\begin{abstract}
$\underline{\text { ABSTRACT }}$
We analyze the differences between companies owned by private equity (PE) investors and similar public companies. We document that PE-owned companies use much stronger incentives for their top executives and have substantially higher debt levels. However, we find little evidence that PE-owned firms outperform public firms in profitability or operational efficiency. We also show that the compensation and debt differences between PE-owned companies and public companies disappear over a very short period (one to two years) after the PE-owned firm goes public. Our results raise questions about whether and how PE firms and the incentives they put in place create value.
\end{abstract}

\author{
Phillip Leslie \\ Stanford University \\ Graduate School of Business \\ 518 Memorial Way \\ Stanford, CA 94305 \\ and NBER \\ pleslie@stanford.edu \\ Paul Oyer \\ Graduate School of Business \\ Stanford University \\ 518 Memorial Way \\ Stanford, CA 94305-5015 \\ and NBER \\ pauloyer@stanford.edu
}




\section{Introduction}

Ostensibly, private equity (PE) firms buy companies, fix them, and then sell them. How is it that PE firms are able to do this and why were the companies unable to fix themselves in the first place? The mantra in the literature is that PE firms mitigate managerial agency problemsthey create value by improving management. ${ }^{1}$ Three mechanisms are emphasized: (i) greater debt disciplines managers, (ii) enhanced governance, and (iii) increased managerial incentives. In this study we examine the changes in managerial incentives caused by PE firms.

Managers as owners is a pillar of the PE approach. But how does the ownership of managers differ between public companies and PE portfolio companies, where managers in both cases have stock options and incentive plans of some kind? Kaplan (1989) first documented differences in the share of CEO equity ownership between publicly traded firms, and firms that had undergone a management buyout. Muscarella and Vetsuypens (1990) provide a similar analysis, but no prior study has examined these effects on post-1990 buyouts, as we do here. It is important to examine more recent data because the buyout market in the 1990s and 2000s operates quite differently from the 1980s (as discussed by Cao and Lerner, 2007), and also because there is reason to believe public corporations may have adopted some of the practices of PE companies.

We compare managerial incentives at public companies with PE-owned companies, using data for U.S. firms during the period 1996 to 2006. A key challenge in this research is obtaining data on managerial incentives at $\mathrm{PE}$ portfolio companies, which are not required to disclose such information. Our approach is to collect data on companies that have PE owners and undergo an IPO (sometimes referred to as a reverse $L B O$ ). In such cases the PE-owned firms are required to disclose the same information as a public company for the two years prior to the IPO. The dataset covers 144 such companies. We then go on to measure whether PE-owned firms outperform their public counterparts in profitability and operational efficiency and to determine if any differences between PE-owned firms and public firms persist after PE owned firms go public. This is important because of a debate as to whether PE firms, in fact, create value or capture value (from pre-buyout investors and employees, say). ${ }^{2}$

\footnotetext{
${ }^{1}$ See Jensen (1986 and 1989).

${ }^{2}$ See, for example: Davis, et al, (2008), and Guo, Hotchkiss and Song (2008).
} 
Numerous papers study executive compensation in public companies. ${ }^{3}$ However, there is very little research on managerial incentives at private companies. ${ }^{4}$ Holmstrom and Kaplan (2001) argue that many public corporations actually adopted the beneficial PE practices in the 1990s, driven by two changes: (i) innovation in information and communication technology made capital markets more efficient (i.e., enhanced disciplining); and (ii) deregulation increased the rewards to restructuring. ${ }^{5}$ Others are more skeptical, such as Bebchuk and Fried (2004) who argue that managerial power continues to drive executive compensation in most public corporations, to the detriment of shareholders.

Since there is reason to expect public companies have adopted some of the practices of PE in the years since Kaplan's study, and also because it is conceivable that PE has significantly evolved, it is timely to assess whether these differences in managerial incentives have persisted. Furthermore, we seek to examine broader evidence on managerial incentives than simply the fraction of equity owned by the CEO (although that is one important measure).

We find that, as conventional wisdom and economic theory suggest, top executive incentives are much stronger at PE-owned companies than at comparable publicly traded companies. More specifically, relative to his counterpart at a publicly traded company in the same industry with similar observable characteristics, the highest paid executive at a PE-owned firm owns approximately twice as large a share of the firm, earns about $12 \%$ less in base pay, and receives a substantially larger share of his cash compensation through variable pay. These differences do not exist at companies before they are bought by PE firms, suggesting that these differences are the result of PE ownership. We do not find, however, that PE-owned firms are substantially more successful than comparable public firms in operating metrics such as return on assets (ROA), operating income, or headcount. While the incentives given to PE-owned firms' managers keep their companies operating at average levels of profitability and efficiency, we do not find evidence that they create significant excess profits. Finally, we show that any differences between PE-owned firms and public firms quickly disappear after PE-owned firms execute an IPO. Within a year of the IPO, the previously PE-owned firm has managerial incentives and debt levels similar to comparable public firms.

\footnotetext{
${ }^{3}$ See Murphy (1999) for a detailed review of the literature.

${ }^{4}$ Exceptions include Kaplan (1989), Muscarella and Vetsuypens (1990) and a case study by Baker and Wruck (1989).

${ }^{5}$ See also Hermalin (2005).
} 
In the next section we describe anecdotal evidence about the range of managerial incentives implemented by $\mathrm{PE}$ firms in their portfolio companies. In Section 3 we summarize the data used in our study. Section 4 then contains our analysis of the differences in managerial incentives between public corporations and PE-owned companies. In Section 5 we examine evidence concerning operational differences, and in Section 6 we explore the longevity of high managerial incentives once a PE-owned firm undergoes an IPO. Section 7 concludes.

\section{Institutional Background on PE Firms}

In this section we provide an overview of some of the key changes that PE firms implement in managerial compensation at their portfolio companies. The information in this section is based on interviews we performed with a half dozen experienced executives at several leading PE firms. The purpose of including this information is to expand our understanding beyond the limited set of facts we are able to study in the formal empirical analysis. It is common in the literature on private equity to propose that enhanced managerial incentives are a major driver of value creation. However, we are unaware of any paper that provides a description of what "enhanced managerial incentives" entails, other than the evidence provided by Kaplan (1989) and Muscarella and Vetsuypens (1990), showing that the fraction of equity owned by the CEO tends to increase. While this is an important feature (which we also examine), the interviews we summarize below clearly indicate that increasing CEO equity is one piece of a more complex set of changes.

Enhanced equity participation is not limited to the CEO. Not surprisingly, all members of the senior management team (Chief Financial Officer, Chief Operations Officer, Chief Technical Officer, and so forth) also obtain significant equity stakes in almost every instance. However, PE firms tend to seek even broader participation. Typically, the top 20 to 80 managers in an acquired company obtain significant equity. The number may vary according to the kind of business: manufacturing firms tend to involve fewer managers in equity participation, while service firms tend to involve more managers. It is not unusual to have 150 or more participating managers. One PE executive told us of a deal that included 500 managers in the equity program.

A very important aspect of the equity programs is that managers are required to contribute 
capital - managers purchase the equity with their own personal funds. One interviewee explained that equity sharing is less about compensation of managers than it is about investment by managers. Arguably, this feature is why managerial equity programs are the cornerstone of the PE model which transforms managers as agents into managers as owners.

Exposing managers to downside risk may be as important for motivating managers as the potential upside. However, the interviewees also emphasized that requiring managers to invest themselves helps to reveal information (as in Lazear, 2005.) If any manager is unwilling to make a significant investment (often described as an investment on par with their home) then it is crucial to understand why. Is it because of personal financial limitations? If so, the PE firm will find creative ways to help the manager invest. Or is it because the manager has private information about the business that brings into question future profitability? Hence, increased equity participation of managers may be as important for mitigating adverse selection as it is for overcoming moral hazard.

Alongside equity investments by managers are stock options which are granted in proportion to the initial investment by managers (although not necessarily the same proportion for all managers in a firm). It is typical for a CEO to obtain two to three times their initial equity in options. Options vest uniformly, often over five years. There may be some controversy surrounding CEO options in particular, since other managers may obtain lower multiples than the CEO, which can be interpreted as a form of kick-back for CEOs to push the deal. A simple example of a CEO equity package is as follows. Suppose the PE firm acquires the target company for $\$ 8$ billion, with $50 \%$ leverage (i.e. $\$ 4$ billion in equity, and $\$ 4$ billion in debt). Suppose the PE firm expects to sell the business for $\$ 16$ billion, yielding a $200 \%$ return on equity (ROE). The CEO may invest $\$ 5$ million of his personal wealth (which is often a rollover of the equity previously owned in the company) and obtain three times that in options for a total stake of $\$ 20$ million. With 200\% ROE, the CEO obtains $\$ 60$ million upon exit. CEO ownership may increase when competition among PE firms for deals is intensified.

PE firms also expend significant effort re-designing cash bonus structures for managers. The changes are customized to specific businesses, but are generally said to involve an increase in the performance weighting and amended performance criteria. It is unclear if the overall level of cash bonuses is increased, but it is probably not decreased. Some interviewees at PE 
firms asserted the changes they implement should have already been done by the firms. ${ }^{6}$ Other interviewees said that such changes reflected strategic re-direction. Others again emphasized that the changes in bonus structures were not necessarily better, and indeed may be worse in some dimensions. This could be because PE firms are not expert in utilizing non-financial measures that encourage leadership development, for example. According to the interviewees, salaries are largely unchanged.

There is an interesting question concerning the role of exit: does the fact that PE firms intend to exit (after five years, say) enhance or diminish the effectiveness of managerial incentives? On the one hand, managers and investors both obtain a liquidity event at the same time, providing alignment around timing. In contrast, with public companies managers may divest sooner than investors would prefer. On the other hand, there can be disagreement between managers and the PE firm concerning the details of exit. For example, managers may prefer not exiting via an IPO, since they are required to hold stock for a minimum period, delaying their liquidity event. Several interviewees made the compelling point that PE firms tend to favor managers when discord arises, since it is essential to maintain a reputation for treating managers well.

It would be ideal to obtain data on all managers equity investments, option grants, and bonus structures, in order to formally analyze/verify the generality of the anecdotal evidence discussed here. By its very nature, it is difficult to obtain information on the practices of private equity firms for a broad sample, let alone such confidential details of managerial incentives. ${ }^{7}$ In the next section we describe the data utilized in our formal analysis, which has some obvious limitations we shall discuss. However, the advantage of our dataset is that we have information about $144 \mathrm{PE}$-owned companies with a clear selection criteria, allowing readers to evaluate the generality of our findings.

\footnotetext{
${ }^{6}$ Consistent with this view, prior research has noted the difficulty of changing compensation structures, and that such changes are more likely in the face bankruptcy or other dramatic changes in ownership structure- people are more willing to accept change when they feel less secure in their jobs. See, for example, Schaefer (1998).

${ }^{7}$ Indeed, even for public companies this level of detail is not usually available.
} 


\section{Data Summary}

We used CapitalIQ to generate lists of two types of firms that have time periods where they are owned by a PE firm and other periods where they are publicly traded (and, therefore, must disclose financial and compensation data). First, we looked at all firms that, according to CapitalIQ, underwent a leveraged buyout (LBO) between 1996 and 2004, and completed an IPO after the LBO but before the end of 2005. We dropped firms that we determined to be venture capital-backed (rather than PE-backed). This is our PE-owned companies sample. In the analysis below, we clarify when we use information about these firms during the private ownership phase and when we use information about these firms after they have gone public. There are 144 firms in this group. Table 1 shows the number of LBOs and IPOs by year for the PE-owned companies in our dataset. Most LBOs are early in the sample period, which is to be expected given the firm must go public by 2005. The IPOs build over the sample years, with a distinct drop during the weak stock market of 2001-2003.

The second type of firm in our dataset, which we refer to as the going private group, is all firms that CapitalIQ lists as having a "going private transaction" between the beginning of 1998 and October of 2007, and for which there is some compensation data available in Standard and Poors' ExecuComp database. There are 89 firms in this group. The annual rate at which firms enter this group went up dramatically in 2004-2006 because of the wave of large PE-backed purchases. These larger firms were more likely to be included in ExecuComp. Table 1 shows the annual rate of going private for firms in this group.

For the PE-owned firms, we downloaded the names of all executives and all compensation information listed by CapitalIQ. We supplemented the compensation information with data from Standard and Poors' ExecuComp database in the few cases where it held relevant information. In most cases, we used firms' proxy statements to fill in compensation information. This compensation data is matched to accounting and stock return data from Compustat and CRSP, respectively.

The PE-owned companies in our sample are a subset of all PE-owned businesses. Strömberg (2008)

finds that only $13 \%$ of PE exits between 1970 and 2007 are via an IPO, which is a necessary condition to enter our sample. One concern is that our sample is not representative of all PE- 
owned companies. Although we are unaware of a particular reason why managerial incentives at PE-owned firms that have an IPO would be different than other PE-owned firms, this is an important caveat to our research.

A more important concern relates to selection. The fact that we do not observe preacquisition incentives for our sample of PE-owned companies raises the question that $\mathrm{PE} \mathrm{ac-}$ quirers may target companies with already high managerial incentives. Hence, a finding that PE-owned companies have high managerial incentives may be due to selection, rather than a causal effect due to changes that are implemented by the new owners. Our second group of firms - the going-private sample - allows us to control for selection because we see the characteristics of firms that are attractive to PE firms but are not yet owned by them.

We were only able to identify five companies that went from public to private and back to public in the time frame of our analysis. We refer to these firms as the public-PE-public group. This sample is too small for formal analysis, but we use one company in this group (Petco) for illustrative purposes.

We also generated a comparison sample that includes all firm-years in ExecuComp that are not in one of the other two samples. ExecuComp oversamples large firms (it includes the entire Standard and Poors' 500), so the comparison sample firms are larger, on average, than the two PE samples. We limit the comparison sample to a subset of smaller firms that more closely match those in the other samples for some of our analysis.

To understand the logic of our identification strategy, note that we had hoped to make more use of the public-PE-public group (or, as Cao and Lerner (2007) refer to them, "reverse LBOs") by analyzing firms' PE ownership stage relative to both a pre-LBO and post-IPO stage. However, the sample size using our time frame and criteria is simply too small. This is because, as Strömberg (2008) shows, only 6\% of PE owned companies were stand-alone public firms before a PE firm bought them. Using two recent prominent investments by Texas Pacific Group (TPG) as examples, Burger King was part of a large British conglomerate and J. Crew Group was private and largely owned by the founder's family before TPG invested in them. As a result, when these companies later went public, it was not possible to track their compensation and performance from a public stage to a private stage and back to a second public phase. 
Further complicating this non-comparability issue is the fact that, as already noted, only $13 \%$ of PE owned firms leave PE ownership through IPO. As a result, we focus on differences between firms in their private phase and those that are public as our estimate of differences between PE-owned firms and public firms. Then we look at differences between public firms and firms that are about to go private, to see if there are systematic differences between public firms and firms that have a PE-owned stage when both groups are publicly held.

Table 2 shows summary statistics for all four groups of firms in our dataset. As expected, the comparison sample is noticeably larger by most measures than any of the other groups. The difference is not as large in the medians, however, because PE firms make fewer investments in the largest corporations that drive up the average size of public firms.

The table shows summary statistics for three measures of managerial incentives for each sample. Each measure corresponds to compensation for the executive with the highest salary at each company in any given year (invariably the CEO). "Executive Ownership" in the table, which we refer to as fraction of the firm's stock owned by the highest paid executive below, is the number of shares that the executive either owns outright or holds options to buy divided by the number of shares outstanding. "Non-Salary Cash Pay" (or variable pay share of cash compensation below) is all cash pay that is not the executive's base salary divided by total cash compensation.

\section{Managerial Incentives in Private Equity Owned Businesses}

As noted in the introduction, one view of PE firms is that they create value in the businesses they acquire as a result of improved management. Some of the improvement may stem from management turnover, but the literature tends to emphasize the role of reduced agency costs. That is, PE mitigates the principal-agent problem between managers and owners via a combination of higher debt levels, enhanced monitoring, and increased incentives. It is conceivable these three factors are complementary, substitutes, or simply additive in their combined effect on firm performance.

\footnotetext{
${ }^{8}$ CapitalIQ does not provide position information. We are in the process of gathering position information for the PE-owned sample (it is available for the other samples in ExecuComp) for use in future drafts.
} 
To illustrate the changes in managerial incentives that take place when a $\mathrm{PE}$ firm acquires a public company, consider the example of Petco and the equity ownership of CEO Bruce Devine, as depicted in Figure 1. This example is one of the five firms in the public-PE-public group discussed above. Between 1995 and 1999, during the initial public phase, Devine owned about $2 \%$ of the equity. After Petco was taken private in 2000, Devine's ownership share sharply increased to about 10\%. Petco undertook an IPO in 2002 and Devine's share was immediately reduced to about $7 \%$, and then continued to fall after that. Devine stepped down as CEO in 2004 but continued as Petco's Chairman. By 2006, he owned about $4 \%$ of Petco. When Petco went private again in 2006, Devine's role in the company had been reduced and he did not increase his stake. PE ownership is associated with higher top management ownership in the case of Petco. We will show below that this example is representative of PE-owned firms.

To examine these effects more generally, we estimate the following specification:

$$
Y_{i t}=\alpha+X_{i t}^{\prime} \beta+\theta_{1} \text { PrivateEquity }_{i t}+\theta_{2} \text { GoingPrivate }_{i t}+\epsilon_{i t}
$$

in which $Y_{i t}$ is one of the three measures for managerial incentives (discussed in Section 3) at firm $i$ in year $t$, and $X$ is a vector of control variables that includes observed firm characteristics (assets, sales, market capitalization, employees, cash/assets), 2-digit SIC dummies, and year dummies. There are two key variables of interest. First, PrivateEquity $y_{i t}$ is a dummy equal to one for companies that are owned by a PE firm. We only include these firms in the last year before they go public (that is, while they are still owned by PE firms.) Second, GoingPrivate $i t$ is a dummy equal to one for public companies in their last year before being acquired by a PE firm. Lastly, $\alpha, \beta, \theta_{1}$ and $\theta_{2}$ are coefficients to be estimated, and $\epsilon$ is an error term that contains unobserved factors which also affect incentives.

Identification of $\theta_{1}$ is based on cross-sectional variation. Even though the dataset includes a time-dimension, for the reasons explained in Section 3 we do not observe the same company before and after going private. Hence, we are unable to include firm fixed effects for the PEowned sample, which would have been helpful to control for unobserved heterogeneity. ${ }^{9}$ Clearly, PE firms do not randomly select their targets. For our purposes, a biased estimate of $\theta_{1}$ will arise if there are firm-specific unobservable factors that are correlated with managerial incentives and the attraction to PE firms.

\footnotetext{
${ }^{9}$ Firm fixed effects are of no use for the Going Private ${ }_{i t}$ sample because we only observe these firms when they are public.
} 
Three factors which are likely to be important determinants of PE acquisitions, which may also affect managerial incentives are: cash reserves, industry factors (such as availability of profitable investments), and macroeconomic factors (such as interest rates). ${ }^{10}$ The above specification includes controls for cash, industry dummies, and time dummies, which control for these three factors, respectively. Hence, $\theta_{1}$ is identified from within-industry and within-year variation.

In addition, the inclusion of Going Private it in equation (1) provides us with a diagnostic for whether the estimate of $\theta_{1}$ is picking up a causal effect of $\mathrm{PE}$, or if $\theta_{1}$ is due to selection-PE firms choosing to acquire public companies with already high managerial incentives. Specifically, if $\theta_{1}=\theta_{2}$ then public companies that are acquired by $\mathrm{PE}$ firms tend to have the same level of incentives, in the year before going private, as do PE-owned firms (prior to IPO). And if $\theta_{2}=0$ then public companies that are acquired by PE firms tend to have the same level of incentives, in the year before going private, as do public firms that do not go private.

The estimates for variations on the above specification are reported in Tables 3,4 and 5 . Each of these tables corresponds to one of the three measures of managerial incentives that were explained in the prior section. For all specifications in these three tables, an observation is an executive-year combination. Also, every specification in these tables includes year dummies.

\subsection{Fraction of Ownership by the Highest Paid Executive}

The dependent variable in Table 3 is the Fraction of Stock Owned by the Highest Paid Executive. Controlling only for year effects, in column (1) we report that the highest paid manager in a PEowned business tends to have 4.8 percentage points more equity than the highest paid managers in public companies. Adding industry dummies in column (2) reduces this difference by a small amount, to $4.4 \%$. Including controls for observed firm characteristics in columns (3) and (4) reduces the difference - with the full set of controls and industry dummies, we estimate the highest paid manager in a PE-owned business has 3.3 percentage points more equity (on average) than their counterpart in public companies. ${ }^{11}$ Columns (5) and (6) show specifications that drop all firm/years (from each group) where the firm employs more people than the 75 th-percentile

\footnotetext{
${ }^{10}$ See Jensen (1989).

${ }^{11}$ The estimate is significantly different from zero with $99 \%$ confidence.
} 
PE-owned firm employs. The results are basically unchanged, which indicates that the findings are robust to the exclusion of large firms. Recall from Table 2 that the mean level of executive ownership (for the highest paid executive) in the comparison sample of public corporations is $3.4 \%$. Hence, the estimate of $3.3 \%$ more ownership associated with PE represent a dramatically higher level of managerial incentives - $100 \%$ higher. As a reality check on the data, note that the coefficient on $\log$ (Assets) in all columns of Table 3 is negative and significant, picking up the expected size effect (managers tend to have a smaller fraction of ownership in larger firms).

As mentioned above, the coefficient on GoingPrivate $\left(\theta_{2}\right)$ indicates whether private equity firms choose targets that already have relatively strong incentives. In the results of the full specification presented in column (4) of Table 3, we report that $\hat{\theta}_{2}$ is insignificantly different from zero. This indicates that public companies that are acquired by $\mathrm{PE}$ firms tend to have the same level of incentives, in the year before going private, as do public firms that do not go private. Unsurprisingly then, we also find that $\hat{\theta}_{2}$ is significantly different from $\hat{\theta}_{1}$, indicating that public companies that are acquired by PE firms tend to have significantly lower level of incentives, in the year before going private, than PE-owned firms.

To better examine the differences between PE and public companies in the distribution of management ownership, rather than just conditional means, Figures 2 and 3 show kernel density estimates of distributions of executive ownership. Figure 2 shows the empirical distributions for each type of firm without conditioning on any other variables. Figure 3 shows the distributions of executive ownership for each type of company conditional on the full set of controls. Specifically, Figure 3 graphs the distributions of the residuals from a regression identical to the one in column 4 of Table 3, except that the regression excludes PrivateEquity and GoingPrivate from the set of explanatory variables. Comparing the distributions in both figures leads to the same qualitative conclusion: compared to public companies, the distribution of equity owned by the highest paid executive in PE-owned businesses has greater variance, and puts more weight on high levels of ownership. In more quantitative terms, in Figure 3 (with controls) the interquartile range of equity ownership is $8.3 \%$ for PE-owned firms, and $3.7 \%$ for public corporations. Also, in Figure 3, the 75th-percentile is 4.1 percentage points higher for PE-owned firms than public firms.

Our estimates likely understate the differences between PE-owned firms and other firms 
because we treat shares and options the same in our analysis. ${ }^{12}$ Options make up a larger part of ownership for the comparison group than for the PE-owned group. But note that each option creates somewhat less incentive and has less value than a share because the price may be below the strike price when the executive wants to exercise the option.

Overall, the regression results in Table 3, as well as Figures 2 and 3, make it clear that top executive ownership is significantly larger (both statistically and economically) in PE-owned firms than at typical publicly-held corporations.

\subsection{Salary of Highest-Paid Executive}

The second measure of managerial incentives we examine is salary. We expect firms that want to provide stronger incentives would pay lower salaries to their executives for at least two reasons. First, when expected payouts from incentives are high, then (assuming the risk premium is not too great) the firm will want to lower base pay so as to keep compensation costs down. Second, lower salaries increase incentives of risk averse workers by increasing the likelihood of low pay (where marginal utility with respect to income is particularly high). We again estimate versions of equation (1), but now with the dependent variable: Log(Salary of Highest Paid Executive). Table 4 contains the results. The number of observations is reduced by three from the above analysis, because there are three firms with zero salary (and the dependent variable is in logs).

Columns (1) and (2) show that salaries are $42-45 \%$ lower at PE-owned companies than public corporations, conditional only on year and industry dummies. Much of this difference is simply because the PE-owned firms are smaller, however. The results for the complete set of controls are given in column (4): we estimate that, on average, the salary of the highest paid executive at PE-owned companies is $11.9 \%$ lower than for similar public companies. Again, in columns (5) and (6) we verify that this finding is robust to excluding large firms in the sample.

The estimated coefficient on the GoingPrivate dummy is insignificantly different from zero in all specifications in Table 4. This provides further confidence that the differences in incentives we are finding at $\mathrm{PE}$ firms compared to public firms is a causal effect, rather than a selection

\footnotetext{
${ }^{12}$ Again, we are somewhat limited by the detail of the compensation and ownership data in CapitalIQ. For the PE-owned sample, we know how many options the executive holds but we do not have details on the date of expiration, strike price, etc.
} 
effect.

\subsection{Variable Pay Share of Cash Compensation}

The third measure of managerial incentives we examine is the Variable Pay Share of Cash Compensation, defined as: (total cash compensation - salary) / (total cash compensation). Cash compensation includes salary and bonuses. Hence, the measure is essentially bonuses. Firms that provide higher incentives will utilize more bonuses, because bonuses are a contingent payoff. We again estimate versions of equation (1), but now with the dependent variable: Variable Pay Share of Cash Compensation. Table 5 contains the results. The number of observations is reduced by one from the analysis of equity ownership because there is one executive-year combination with zero total cash compensation.

The results are presented in Table 5. The difference in variable pay share between PE firms and public companies is significant (with $95 \%$ confidence) in all columns. In the full specification reported in column (4), we find that PE-owned businesses tend to provide $12.6 \%$ higher variable pay shares than public companies. Recall from the discussion of anecdotal evidence in Section 2 that our interviewees did not have a strong sense of whether bonuses would be higher at PEowned companies.

The PrivateEquity coefficient changes when firm controls are added because larger firms pay more overall and, given that executives are risk averse, can put more compensation at risk. Relative to the large public firms in the control sample, PE-owned firms have both lower salaries and lower incentive-based cash compensation, so that the fraction that is variable works out about the same for both groups. However, relative to public firms of the same size, PE-owned firms have lower salaries and more variable cash compensation.

The estimated coefficient on the GoingPrivate dummy is insignificantly different from zero in specifications (1) to (4) in Table 5. This variable, however, is significantly positive and similar to the PrivateEquity coefficient specification in columns (5) and (6). This suggests that, excluding the large firms they acquire, $\mathrm{PE}$ firms tend to acquire companies that provide already high bonuses. This is the only measure of incentives, specification, and subsample for which we found any evidence of a selection effect on incentives. 


\subsection{Heterogeneous Effects}

The above analysis focuses on mean differences in managerial incentives between PE-owned and public companies. However, these differences may also depend on other interesting factors. For instance, there is reason to expect that the differences between public corporations and PEowned businesses have decreased over time, as public companies learn to mimic the practices of PE firms. Or as Holmstrom and Kaplan (2001) argue, public firms have been catching up with PE practices during the 1990s, driven by: (i) innovation in information and communications technology made capital markets more efficient (i.e., enhanced disciplining); and (ii) deregulation increased the rewards to restructuring. We therefore ask whether the gap in managerial incentives between PE companies and public companies has been shrinking over time?

To examine this possibility, we generalize the specification in equation (1) to allow $\theta_{1}$ and $\theta_{2}$ to have different values in the years 1996-2001 and 2002-2005. In Table 6 we report the results for two different measures of managerial incentives: fraction of equity owned by the highest paid executive, and salary of the highest paid executive (the first two measures examined above). In each case we report the estimates for the coefficient on PrivateEquity interacted with a group dummy. In column (1) it is apparent that the difference between PE and public companies in terms of equity ownership has not changed over time. However, in column (2) of the table it is apparent that the average difference in salary has increased over time, in contrast to what we expected. Hence, the evidence does not indicate convergence over time in managerial incentives between public and PE-owned companies.

A second form of heterogeneity we explore is size effects: is the gap in managerial incentives between PE companies and public companies different for big versus small companies? This is of interest because agency costs are likely to be higher in larger companies (e.g. harder to monitor) and incentives may create more risk for a CEO in a larger company. Also, there is a trend towards bigger PE acquisitions. In columns (3) and (4) of Table 6 we report estimates for the equity ownership and salary measures, for the largest $25 \%$ of PE-owned firms, and the smallest $25 \%$ of PE-owned firms. The measure of size is based on the number of employees (of the PEowned company). For both measures, we find that incentives in PE-owned companies, relative to public companies, are greater in large firms. An explanation for this finding is that agency problems are greater in large companies, leading PE firms to implement stronger incentives. 
A third form of heterogeneity relates to differences across PE firms, which may differ in the degree to which they emphasize managerial incentives versus other mechanisms such as replacing management, enhanced oversight, and the importance of debt. ${ }^{13}$ In other words, how homogeneous are the practices of PE firms, and how substitutable are they? As a basic test of such differences, we ask whether top-tier PE firms tend to implement different managerial incentives than other PE firms? To identify the top-tier PE firms, we adopt the "power list" in the March 5, 2007, issue of Fortune: Blackstone, KKR, Carlyle, TPG, Bain Capital, Providence Equity Partners, Apollo Advisors, Warburg Pincus, Cerberus, and Thomas H. Lee. In columns (5) and (6) of Table 6 we show that the differences in managerial incentives between the top-tier PE firms and non-top-tier firms are insignificant. This is far from conclusive, but it suggests that different PE firms tend to implement similar changes at the firms they acquire.

\subsection{Summary}

To summarize the key results in this section, we find that, relative to public corporations, PEowned firms: (i) provide the highest paid executive with 3.3 percentage points more equity (that is, approximately twice as much); (ii) $11.9 \%$ lower salary; and (iii) $12.6 \%$ higher variable pay share. These estimates are all based on a specification in which we control for year dummies, industry dummies, and various observed firm characteristics. Our analysis also indicates these estimates are not driven by selection effects and can plausibly be interpreted as the causal impact of PE ownership.

How do these results compare to prior research? Kaplan (1989) did not analyze salaries and variable pay shares, but did analyze equity shares. Studying buyouts between 1980 and 1986, Kaplan found that mean pre-buyout CEO equity share was $7.1 \%$ and the mean post-buyout CEO equity share was $14.7 \%$ - an increase of $7.6 \%$, or roughly twice the mean ownership of prebuyout CEOs. ${ }^{14}$ Compared to the data used in this study, the average level of equity ownership by the CEO is much higher, both before and after going private. However, the proportional change is roughly similar in both studies - around two times greater ownership share as a PE portfolio company.

\footnotetext{
${ }^{13}$ See Cressy, Munari and Malipiero (2007) for a related analysis of differences in PE performance based on the degree of specialization.

${ }^{14}$ Conditioning on the sub-sample of CEOs that were present before and after the buyout, Kaplan found that equity shares increased from $6.4 \%$ to $14.5 \%$, on average.
} 
Muscarella and Vetsuypens (1990) study 72 companies that had an IPO between 1976 and 1987, and had previously undergone an LBO (similar to our sample design). They find the mean fraction of equity owned by the CEO was $17.7 \%$ when private, and $12.7 \%$ when public. The level of these magnitudes is more in-line with Kaplan (1989), but the proportional differences are lower than in our study (and in Kaplan, 1989).

\section{Operational Differences Between Private Equity Owned Businesses and Public Corporations}

Having shown that PE firms significantly (statistically and economically) increase managerial incentives relative to public companies, based on U.S. data for the period 1996 to 2004, the question naturally arises as to whether there are corresponding improvements in operational performance? This question has actually received much more attention in the literature than the changes in managerial incentives by PE firms. Indeed, there are numerous papers, with a wide range of results, looking for evidence of value creation by PE firms. In Table 7 we present a summary of this literature. Conclusions depend on what measure, time period, geographic location of the sample is used and how the sample is constructed (type of acquisition and type of exit). In this section we also examine this kind of evidence for our sample.

Although not a measure of performance, as a reality check on the data, we first analyze the changes in the importance of debt. We analyze the debt-assets ratio instead of the more conventional debt-equity ratio, because negative equity is not uncommon in the data. Again, using Petco as an example, Figure 4 shows that PE ownership is associated with a dramatic increase in debt. Petco's debt returned to its pre-PE level slowly over a few years after it went public again. We will again show that Petco is reasonably typical of other PE-owned firms.

To examine changes in debt for the broader sample, we regress the debt-assets ratio on the same controls as column (4) in Tables 3 to 5. The results are provided in column (1) of Table 8. As expected, we find that PE ownership causes an average increase of $51.1 \%$ in the debtassets ratio. We also find that the debt-assets ratio in going-private companies is insignificantly different from the public company control sample, indicating that this effect is not driven by selection. 
We now turn to measures of profitability and operational efficiency. First, Figure 5 shows ROA at Petco over its various forms of ownership. The graph indicates that, if anything, Petco was less profitable during its years under PE ownership. A trend up in profits ended when the firm was bought by TPG and Leonard Green in 2000, and another one began after the firm was returned to public ownership. However, Petco's ownership coincided with a recession, so it is important to look at this in a regression context where we can control for time effects.

Using the same regression framework and controls we used for the debt-assets ratio and the incentive measures, we examine the following performance measures: Return on Assets (ROA), EBITDA / (Total Assets), Sales Per Employee, and Employees / (Total Assets). The results for each of these dependent variables are reported in columns (2) to (5) of Table 8. The only one of these measures to show a significant (and positive) effect from PE ownership is Sales Per Employee. In this case, there is also no significant difference between the going-private firms and the public controls.

Sales Per Employee aside, the general message of the analysis in this section is that we find little evidence of PE causing performance improvements. As shown in Table 7, this is not unprecedented in the prior research. We also looked at the correlation between the level of incentives and these measures of profits and efficiency, without finding any obviously strong relationships. Thus far, we have not found any evidence that the increased incentives we documented in the prior section improve bottom-line performance. While one might suspect that this is because the firms that go into PE ownership are often turnarounds and their PE owners are successful in returning them to financial health, this would imply that firms in our going private sample would be underperforming their peers at the time we measure them. We see no evidence to support that idea. While this lack of evidence of operational efficiency advantages of PE ownership could be caused by the limits of using accounting data to compare public and private companies, by outliers, or other data issues, it is puzzling that our finding of significant increases in incentives is not accompanied by performance improvements. 


\section{Longevity of Increased Incentives after IPO}

One of the virtues of our dataset is that we focus on PE-owned companies that undergo an IPO, which allows us to examine changes after the firm transitions from private to public. So we now analyze the longevity of the higher degree of managerial incentives once these companies go public. There are at least a couple of reasons why this is interesting. If the higher degree of managerial incentives during the private ownership phases, rapidly fall after IPO (or reverse buyout), then it suggests PE firms do not implement long-lasting organizational changes in the companies they acquire. Also, PE firms have been criticized by some commentators for "quick flips": buying companies and selling them shortly after (in one year, say) for a large profit. The suggestion is that one year is too short a time to implement real or permanent improvements in an organization, so the profit must stem from either underpaying for the company or overselling it to the new owners. However, if managers continue to maintain high equity stakes in their company after the IPO, then this suggests the IPO valuation may not be artificially high, because the managers also have significant wealth at stake.

To examine the longevity of managerial incentives following reverse buyouts, we generalize equation (1) in the following way:

$$
Y_{i t}=\alpha+X_{i t}^{\prime} \beta+\sum_{j=-1}^{4} \theta_{j} \text { Private Equity }_{i t}+\sum_{k=-5}^{-1} \theta_{k} \text { GoingPrivate } i t+\epsilon_{i t} .
$$

Instead of including only the first available observation for PE-owned firms that go public, we now include annual observations for the year before the IPO and each subsequent year up to four years after the IPO. The $\theta_{j}$ 's capture how managerial incentives (or other dependent variables) evolve at these firms from just before the IPO until four years after. Similarly, instead of including only the last public year for the going private sample, we now include all available years and the $\theta_{k}$ 's track how incentives evolve in the years leading up to the purchase by a PE firm.

Rather than present regression coefficients, we graph the $\theta$ 's and corresponding $95 \%$ confidence intervals. Figure 6 shows the $\theta$ 's from a regression that estimates equation 2 with fraction ownership of the highest paid executive as the dependent variable and all the control variables used in column 4 of Table 3 . The graph shows that the $\theta_{k}$ 's are generally small for all years leading up to firms going private and there is no obvious trend before PE investments. The evo- 
lution of the PE-owned sample (and the $\theta_{j}$ 's), however, shows that executive ownership drops quickly and substantially right after the IPO. Managerial ownership is very high before the IPO and at the time of the IPO, but quickly drops to levels similar to public firms. This suggests that whatever incentives $\mathrm{PE}$ firms put in place for managers of the companies they own last only as long as the PE ownership lasts. The firms do not appear to put in place different incentive systems that outlive the PE investment.

Figure 7 presents similar time trends for the salary of the highest paid executive. Again, the $\theta_{k}$ 's are small, insignificant, and do not exhibit a trend leading up to the PE investment. The PE-owned firms again revert to compensation systems that are equivalent to those of public companies, though salary takes longer (three to four years) to reach public company levels than stock ownership does. Again, it appears that any incentive changes made by PE investors are only in place during the PE phase.

To the best of our knowledge, no prior study has examined the longevity of managerial incentives following reverse buyouts. However, several prior studies have also examined the longevity of firm performance after reverse buyouts. Most recently Cao and Lerner (2007) find that reverse buyouts tend to outperform (measured by ROA) IPOs for up to five years, and this is robust throughout the period 1980 to $2002 .{ }^{15}$

In Figure 8 we confirms that the capital structure effects of private equity (that is, more debt relative to public firms) is also limited to the PE phase. Debt-asset ratios are much higher immediately before and around the time of the IPO but revert to typical public company levels within a year or two. Finally, Figure 9 looks at trends in the one operational measure where we found some reason to think PE owned firms perform well-sales per employee. The individual year $\theta_{j}$ 's and $\theta_{k}$ 's are measured with considerable error, so we do not want to read too much into this graph. But, taking the $\theta_{k}$ coefficients at face value, it appears that PE firms buy firms that are trending down in terms of sales/employee. Also, to the extent that firms emerge from PE ownership with high sales/employee, that effect appears to dissipate over a few years.

Overall, the graphs and the corresponding regressions in this section suggest that, while there are some important differences between PE-owned firms and comparable public companies, these differences are limited to the period in companies' lives when they are owned by PE firms. We

\footnotetext{
${ }^{15}$ See also the references cited in Cao and Lerner (2007).
} 
do not find evidence that these firms put in place incentive systems or operational efficiency that outlives their ownership.

\section{Conclusion}

As Murphy (1999) remarks in the first sentence of his article: "Few issues in the history of the modern corporation have attracted the attention garnered by executive compensation in United States companies." But nearly all of that research concerns public companies, and there is good reason to believe managerial incentives are quite different in private firms - increased managerial incentives are often cited as one of the key drivers of value creation in companies taken private (PE buyouts). A number of questions immediately arise. Do PE firms in fact increase managerial incentives? If so, by how much? How deep do increased incentives tend to go in such companies? Are there other differences with public ocmpanies in terms of how incentives are structured? Why don't public companies provide similar incentives? Are public companies moving in this direction? How important is increasing managerial incentives as a driver of value creation in PEowned companies? When the PE owner exits (by IPO, say) are the higher incentives enduring? These are core questions for understanding the mechanisms by which PE firms create value and generate returns for their investors. Furthermore, these questions are just as relevant to understanding the causes and consequences of executive compensation in public corporations.

Using data from 144 companies that were owned by PE investors and subsequently went public during the period 1996 to 2005, we study differences in incentives, capital structure, and operational performance between PE-owned companies and comparable public corporations. Our research provides a more current and broader analysis of the changes in managerial incentives that take place in private equity buyouts of public companies than the prior literature. In doing so, we make progress on some of the above questions, although certainly not all.

We find that top managers of PE-owned firms have substantially higher-powered compensation contracts than their counterparts at public companies: executives at PE-owned firms own more equity, have lower salaries, and get more of their annual cash compensation in variable pay than managers at public firms. Executives at firms that are public but about to get bought by PE firms exhibit no such differences relative to other public firms, suggesting that PE firms 
implement these incentive contracts, rather than selecting firms that already use high-powered incentives. We also verify that PE firms hold much more debt than otherwise comparable public firms (not surprisingly).

We showed that these differences between PE-owned and public firms do not extend to most measures of operational efficiency and they are quickly undone when firms return to public ownership. These results raise questions about the value created by private equity. Why are high powered incentive contracts valuable to PE firms if they do not correspond to higher returns, and why are public shareholders willing to pay PE firms handsome profits for the firms they take public if these firms quickly take on the characteristics of similar public firms?

While it is puzzling that increased managerial incentives in PE-owned companies are seemingly not associated with improved performance, it should be noted that the question of whether managerial incentives matter has not been resolved in the broader human resources literature (see the discussion in Murphy, 1999). ${ }^{16}$ It is conceivable that managerial incentives are not a primary determinant of profits (at least within the range of incentives we observe.) If they were, and if $\mathrm{PE}$ firms are somehow uniquely capable of increasing incentives in ways that public firms are unable to, then PE activity might be less sensitive to debt market conditions than it appears to be (see Axelson, et al, 2008). ${ }^{17}$

\footnotetext{
${ }^{16}$ See also Hall and Liebman (1998), and Himmelberg, Hubbard, and Palia (1999).

${ }^{17}$ See also the indirect evidence presented by Bargeron, et al (2007).
} 


\section{References}

Axelson, U., T. Jenkinson, P. Strömberg, M.S. Weisbach (2008): "Leverage and Pricing in Buyouts: An Empirical Analysis," Mimeo.

Baker, G.P. and K.H. Wruck (1989): "Organizational Changes and Value Creation in Leveraged Buyouts: The Case of The O.M. Scott \& Sons Company," Journal of Financial Economics, 25, 163-90.

Bargeron, L., F. Schlingemann, R.M. Stulz, and C. Zutter (2007): "Why Do Private Acquirers Pay So Little Compared to Public Acquirers?" NBER Working Paper, w13061.

Bebchuk, L.A. and J.M. Fried (2004): Pay Without Performance: The Unfulfilled Promise of Executive Compensation, Harvard University Press.

Cao, J. and J. Lerner (2007): "The Performance of Reverse Leveraged Buyouts," forthcoming in Journal of Financial Economics.

Cressy, R., F. Munari and A. Malipiero (2007): "Playing to their Strengths? Evidence that Specialization in the Private Equity Industry Confers Competitive Advantage," forthcoming in Journal of Corporate Finance.

Davis, S.J., J. Haltiwanger, R. Jarmin, J. Lerner, and J. Miranda (2008): "Private Equity and Employment," Mimeo.

Desbrieres, P. and A. Schatt (2002): "The Impacts of LBOs on the Performance of Acquired Firms: The French Case," Journal of Business Finance and Accounting, 29(5), 695-729.

Guo, S., E.S. Hotchkiss and W. Song (2008): "Do Buyouts (Still) Create Value?" Mimeo.

Hall, B. and J. Liebman (1998): “Are CEOs Really Paid Like Bureaucrats?" Quarterly Journal of Economics, 112(3), 653-91.

Harris, R., D.S. Siegel, and M. Wright (2005): "Assessing the Impact of Management Buyouts on Economic Efficiency: Plant-Level Evidence from the United Kingdom," Review of Economics and Statistics, 87(1), 148-53.

Hermalin, B. (2005): "Trends in Corporate Governance," Journal of Finance, 60(5), 2351-84.

Himmelberg, C.P., R.G. Hubbard, and D. Palia (1999): "Understanding the Determinants of Managerial Ownership and the Link Between Ownership and Performance," Journal of Financial Economics, 53, 353-84.

Holmstrom, B. and S.N. Kaplan (2001): "Corporate Governance and Merger Activity in the United States: Making Sense of the 1980s and 1990s," Journal of Economic Perspectives, $15(2), 121-44$. 
Jensen, M.C. (1986): "Agency Costs of Free Cash Flow, Corporate Finance, and Takeovers," American Economic Review, 76(2), 323-29.

Jensen, M.C. (1989): "Eclipse of the Public Corporation," Harvard Business Review, SeptemberOctober, 61-74.

Kaplan, S. (1989): "The Effects of Management Buyouts on Operating Performance and Value," Journal of Financial Economics, 24, 217-54.

Lazear, E.P. (2005): "Output-Based Pay: Incentives or Sorting?" in S.W. Polachek (ed.), Research in Labor Economics, vol. 23, 1-25.

Lichtenberg, F.R. and D.S. Siegel (1990): "The Effects of Leveraged Buyouts on Productivity and Related Aspects of Firm Behavior," Journal of Financial Economics, 27, 165-94.

Meuleman, M., K. Amess, M. Wright, and L. Scholes (2008): "Agency, Strategic Entrepreneurship and the Performance of Private Equity Backed Buyouts," Mimeo.

Murphy, K.J. (1999): "Executive Compensation," in O. Ashenfelter and D. Card (ed.s), Handbook of Labor Economics, vol. 3, 2485-563.

Muscarella, C.J. and M.R. Vetsuypens (1990): "Efficiency and Organizational Structure: A Study of Reverse LBOs," Journal of Finance, 45(5), 1389-413.

Ravenscraft, D.J. and F.M. Scherer (1987): "Life After Takeover," Journal of Industrial Economics, 36(2), 147-56.

Schaefer, S. (1998): "Influence Costs, Structural Inertia, and Organizational Change," Journal of Economics and Management Strategy, 7(2), 238-263.

Strömberg, P. (2008): "The New Demography of Private Equity," Globalization of Alternative Investments, Working Papers Volume 1, World Economic Forum.

Smith, A.J. (1990): "Corporate Ownership Structure and Performance: The Case of Management Buyouts," Journal of Financial Economics, 27, 143-64.

Vinten, F. (2007): "The Performance of Private Equity Buyout Fund Owned Firms," Mimeo.

Weir, C., P. Jones, and M. Wright (2008): "Public to Private Transactions, Private Equity and Performance in the U.K.: An Empirical Analysis of the Impact of Going Private," Mimeo.

Wright, M., S. Thompson, and K. Robbie (1992): "Venture Capital and Management-Led Buy-Outs: European Evidence," Journal of Business Venturing, 7(1), 47-71.

Wright, M., N. Wilson, and K. Robbie (1997): "The Longer Term Performance of Management Buy-Outs," Frontiers of Entrepreneurship Research, 555-569. 
Table 1. Timing of Ownership Transitions

\begin{tabular}{lcccc}
\hline \hline & \multicolumn{2}{c}{ Private Equity } & & Going Private \\
\cline { 2 - 3 } 1996 & Acquisition & IPO & & Acquisition \\
\cline { 2 - 3 } 1997 & 25 & 9 & \\
1998 & 20 & 13 & 2 \\
1999 & 21 & 10 & 9 \\
2000 & 28 & 17 & 5 \\
2001 & 9 & 15 & 5 \\
2002 & 10 & 12 & 2 \\
2003 & 13 & 6 & 2 \\
2004 & 10 & 29 & 4 \\
2005 & 8 & 33 & 14 \\
2006 & & & 30 \\
\hline Total & 144 & 144 & 89 \\
\hline \hline
\end{tabular}

"Private Equity" sample includes firms where CapitalIQ indicates a major investment by a private equity firm ("acquisition") and a subsequent IPO between 1996 and 2005. "Going Private" firms are companies that CapitalIQ indicates had a "going private" transaction in 1998 or later, and that are in the ExecuComp database for at least one year between 1995 and 2006. 
Table 2. Summary Statistics

\begin{tabular}{|c|c|c|c|}
\hline & Private Equity & Going Private & Comparison Sample \\
\hline Firms & 144 & 89 & 2555 \\
\hline Firm/Years & 662 & 711 & 19,768 \\
\hline \multirow[t]{3}{*}{ Assets } & $\$ 832$ & $\$ 3,728$ & $\$ 14,983$ \\
\hline & {$[335]$} & {$[1,091]$} & {$[1,733]$} \\
\hline & $(1,522)$ & $(6,587)$ & $(77,480)$ \\
\hline \multirow[t]{3}{*}{ Sales } & $\$ 671$ & $\$ 2,455$ & $\$ 5,326$ \\
\hline & {$[279]$} & {$[1,053]$} & {$[1,259]$} \\
\hline & $(1,324)$ & $(3,561)$ & $(15,854)$ \\
\hline \multirow[t]{3}{*}{ Market Capitalization } & $\$ 874$ & $\$ 3,107$ & $\$ 7,662$ \\
\hline & {$[562]$} & {$[902]$} & {$[1,735]$} \\
\hline & $(1,065)$ & $(5,100)$ & $(23,895)$ \\
\hline \multirow[t]{3}{*}{ Employees } & 3,640 & 18,747 & 18,800 \\
\hline & {$[1,602]$} & {$[7,100]$} & {$[4,803]$} \\
\hline & $(6,562)$ & $(36,574)$ & $(59,152)$ \\
\hline \multirow[t]{3}{*}{ Cash/Assets } & $6.9 \%$ & $10.9 \%$ & $16.2 \%$ \\
\hline & {$[3.3 \%]$} & {$[6.2 \%]$} & {$[9.0 \%]$} \\
\hline & $(10.2 \%)$ & $(13.0 \%)$ & $(17.8 \%)$ \\
\hline \multirow[t]{3}{*}{ Executive Ownership } & $8.76 \%$ & $5.29 \%$ & $3.44 \%$ \\
\hline & {$[5.53 \%]$} & {$[2.26 \%]$} & {$[1.77 \%]$} \\
\hline & $(14.77 \%)$ & $(7.42 \%)$ & $(5.59 \%)$ \\
\hline \multirow[t]{3}{*}{ Salary } & $\$ 405 \mathrm{~K}$ & $\$ 688 \mathrm{~K}$ & $\$ 721 \mathrm{~K}$ \\
\hline & {$[\$ 376 \mathrm{~K}]$} & {$[\$ 675 \mathrm{~K}]$} & {$[\$ 654 \mathrm{~K}]$} \\
\hline & $(\$ 190 \mathrm{~K})$ & $(\$ 312 \mathrm{~K})$ & $(\$ 377 \mathrm{~K})$ \\
\hline \multirow[t]{3}{*}{ Non-Salary Cash Pay } & $42.4 \%$ & $35.1 \%$ & $43.6 \%$ \\
\hline & {$[46.2 \%]$} & {$[41.1 \%]$} & {$[49.2 \%]$} \\
\hline & $(23.1 \%)$ & $(26.6 \%)$ & $(24.4 \%)$ \\
\hline
\end{tabular}

See notes to Table 1 for description of sample in each column. "Private Equity" firm characteristics are for year after IPO. "Going Private" firm characteristics are for last full year as a public company. "Comparison Sample" firm characteristics are for 2004. Firm characteristic information is in \$millions. "Pay information is for all available executive-years. "Non-Salary Cash Pay" is the fraction of an executives cash compensation that is not salary: (total cash compensation - salary)/ total cash compensation. Sample medians are in brackets and standard deviations are in parentheses. 
Table 3. Effect of Private Equity on Fraction of Stock Owned by the Highest Paid Executive

\begin{tabular}{|c|c|c|c|c|c|c|}
\hline & (1) & $(2)$ & $(3)$ & (4) & (5) & $(6)$ \\
\hline PrivateEquity & $\begin{array}{c}0.0476 \\
(0.0055)\end{array}$ & $\begin{array}{c}0.0437 \\
(0.0054)\end{array}$ & $\begin{array}{c}0.0343 \\
(0.0053)\end{array}$ & $\begin{array}{c}0.0326 \\
(0.0052)\end{array}$ & $\begin{array}{c}0.0275 \\
(0.0066)\end{array}$ & $\begin{array}{c}0.0226 \\
(0.0064)\end{array}$ \\
\hline GoingPrivate & $\begin{array}{c}0.0188 \\
(0.0070)\end{array}$ & $\begin{array}{c}0.0100 \\
(0.0068)\end{array}$ & $\begin{array}{c}0.0135 \\
(0.0067)\end{array}$ & $\begin{array}{c}0.0094 \\
(0.0066)\end{array}$ & $\begin{array}{c}0.0026 \\
(0.0118)\end{array}$ & $\begin{array}{l}-0.0008 \\
(0.0113)\end{array}$ \\
\hline $\log ($ Assets $)$ & & & $\begin{array}{l}-0.0084 \\
(0.0005)\end{array}$ & $\begin{array}{l}-0.0102 \\
(0.0008)\end{array}$ & $\begin{array}{l}-0.0085 \\
(0.0008)\end{array}$ & $\begin{array}{l}-0.0083 \\
(0.0012)\end{array}$ \\
\hline Cash/Assets & & & $\begin{array}{c}0.0131 \\
(0.0028)\end{array}$ & $\begin{array}{c}0.0139 \\
(0.0031)\end{array}$ & $\begin{array}{c}0.0102 \\
(0.0037)\end{array}$ & $\begin{array}{c}0.0138 \\
(0.0042)\end{array}$ \\
\hline $\log ($ Sales $)$ & & & $\begin{array}{l}-0.0036 \\
(0.0008)\end{array}$ & $\begin{array}{l}-0.0027 \\
(0.0010)\end{array}$ & $\begin{array}{l}-0.0023 \\
(0.0011)\end{array}$ & $\begin{array}{l}-0.0034 \\
(0.0013)\end{array}$ \\
\hline $\log ($ Employees $)$ & & & $\begin{array}{c}0.0036 \\
(0.0005) \\
\end{array}$ & $\begin{array}{c}0.0038 \\
(0.0007) \\
\end{array}$ & $\begin{array}{c}0.0028 \\
(0.0010) \\
\end{array}$ & $\begin{array}{c}0.0031 \\
(0.0011)\end{array}$ \\
\hline 2-digit SIC dummies & no & yes & no & yes & no & yes \\
\hline Sample & All & All & All & All & Drop Largest & Drop Largest \\
\hline$R^{2}$ & 0.0087 & 0.0744 & 0.0755 & 0.1241 & 0.0484 & 0.1366 \\
\hline Observations & 20,001 & 20,001 & 20,001 & 20,001 & 9,680 & 9,680 \\
\hline
\end{tabular}

Each regression includes dummies for the years 1995 through 2006. 
Table 4. Effect of Private Equity on Log(Salary of Highest Paid Executive)

\begin{tabular}{|c|c|c|c|c|c|c|}
\hline & (1) & $(2)$ & $(3)$ & $(4)$ & $(5)$ & (6) \\
\hline PrivateEquity & $\begin{array}{l}-0.4474 \\
(0.0413)\end{array}$ & $\begin{array}{l}-0.4163 \\
(0.0390)\end{array}$ & $\begin{array}{l}-0.1338 \\
(0.0286)\end{array}$ & $\begin{array}{l}-0.1188 \\
(0.0271)\end{array}$ & $\begin{array}{l}-0.1024 \\
(0.0328)\end{array}$ & $\begin{array}{l}-0.0917 \\
(0.0312)\end{array}$ \\
\hline GoingPrivate & $\begin{array}{l}-0.0216 \\
(0.0526)\end{array}$ & $\begin{array}{l}-0.0119 \\
(0.0494)\end{array}$ & $\begin{array}{c}0.0276 \\
(0.0362)\end{array}$ & $\begin{array}{c}0.0113 \\
(0.0341)\end{array}$ & $\begin{array}{c}0.0096 \\
(0.0582)\end{array}$ & $\begin{array}{l}-0.0141 \\
(0.0547)\end{array}$ \\
\hline $\log ($ Assets $)$ & & & $\begin{array}{c}0.0756 \\
(0.0026)\end{array}$ & $\begin{array}{c}0.1015 \\
(0.0040)\end{array}$ & $\begin{array}{c}0.1008 \\
(0.0037)\end{array}$ & $\begin{array}{c}0.1201 \\
(0.0056)\end{array}$ \\
\hline Cash/Assets & & & $\begin{array}{l}-0.0109 \\
(0.0150)\end{array}$ & $\begin{array}{l}-0.0072 \\
(0.0160)\end{array}$ & $\begin{array}{c}0.0624 \\
(0.0185)\end{array}$ & $\begin{array}{c}0.0638 \\
(0.0201)\end{array}$ \\
\hline $\log ($ Sales $)$ & & & $\begin{array}{c}0.0999 \\
(0.0042)\end{array}$ & $\begin{array}{c}0.0970 \\
(0.0050)\end{array}$ & $\begin{array}{c}0.0970 \\
(0.0055)\end{array}$ & $\begin{array}{c}0.0888 \\
(0.0062)\end{array}$ \\
\hline Log(Employees) & & & $\begin{array}{c}0.0509 \\
(0.0029)\end{array}$ & $\begin{array}{c}0.0362 \\
(0.0036)\end{array}$ & $\begin{array}{c}0.0124 \\
(0.0049)\end{array}$ & $\begin{array}{c}0.0164 \\
(0.0055)\end{array}$ \\
\hline 2-digit SIC dummies & no & yes & no & yes & no & yes \\
\hline Sample & All & All & All & All & Drop Largest & Drop Largest \\
\hline$R^{2}$ & 0.0745 & 0.1931 & 0.5626 & 0.6163 & 0.4032 & 0.4819 \\
\hline Observations & 19,998 & 19,998 & 19,998 & 19,998 & 9,680 & 9,680 \\
\hline
\end{tabular}

Each regression includes dummies for the years 1995 through 2006. 
Table 5. Effect of Private Equity on Variable Pay Share of Cash Compensation

\begin{tabular}{|c|c|c|c|c|c|c|}
\hline & $(1)$ & $(2)$ & $(3)$ & $(4)$ & $(5)$ & $(6)$ \\
\hline PrivateEquity & $\begin{array}{c}0.0430 \\
(0.0206)\end{array}$ & $\begin{array}{c}0.0464 \\
(0.0200)\end{array}$ & $\begin{array}{c}0.1346 \\
(0.0194)\end{array}$ & $\begin{array}{c}0.1259 \\
(0.0190)\end{array}$ & $\begin{array}{c}0.1235 \\
(0.0217)\end{array}$ & $\begin{array}{c}0.1122 \\
(0.0213)\end{array}$ \\
\hline GoingPrivate & $\begin{array}{l}-0.0163 \\
(0.0261)\end{array}$ & $\begin{array}{l}-0.0015 \\
(0.0253)\end{array}$ & $\begin{array}{c}0.0155 \\
(0.0245)\end{array}$ & $\begin{array}{c}0.0095 \\
(0.0239)\end{array}$ & $\begin{array}{c}0.1186 \\
(0.0385)\end{array}$ & $\begin{array}{c}0.1007 \\
(0.0374)\end{array}$ \\
\hline $\log ($ Assets $)$ & & & $\begin{array}{c}0.0228 \\
(0.0018)\end{array}$ & $\begin{array}{c}0.0113 \\
(0.0028)\end{array}$ & $\begin{array}{c}0.0171 \\
(0.0025)\end{array}$ & $\begin{array}{c}0.0158 \\
(0.0038)\end{array}$ \\
\hline Cash/Assets & & & $\begin{array}{c}0.1120 \\
(0.0102)\end{array}$ & $\begin{array}{c}0.1105 \\
(0.0112)\end{array}$ & $\begin{array}{c}0.1316 \\
(0.0122)\end{array}$ & $\begin{array}{c}0.1246 \\
(0.0137)\end{array}$ \\
\hline $\log ($ Sales $)$ & & & $\begin{array}{c}0.0494 \\
(0.0028)\end{array}$ & $\begin{array}{c}0.0546 \\
(0.0035)\end{array}$ & $\begin{array}{c}0.0617 \\
(0.0036)\end{array}$ & $\begin{array}{c}0.0573 \\
(0.0042)\end{array}$ \\
\hline $\log ($ Employees $)$ & & & $\begin{array}{l}-0.0203 \\
(0.0020)\end{array}$ & $\begin{array}{l}-0.0119 \\
(0.0025)\end{array}$ & $\begin{array}{l}-0.0261 \\
(0.0033)\end{array}$ & $\begin{array}{l}-0.0209 \\
(0.0037)\end{array}$ \\
\hline 2-digit SIC dummies & no & yes & no & yes & no & yes \\
\hline Sample & All & All & All & All & Drop Largest & Drop Largest \\
\hline$R^{2}$ & 0.0485 & 0.1209 & 0.1629 & 0.2128 & 0.1124 & 0.1765 \\
\hline Observations & 20,000 & 20,000 & 20,000 & 20,000 & 9,680 & 9,680 \\
\hline
\end{tabular}

Variable pay share of cash compensation is defined as (total cash compensation - salary) / (total cash compensation). Each regression includes dummies for the years 1995 through 2006. 
Table 6. Heterogeneity in Private Equity Effects on Ownership

\begin{tabular}{lcccccc}
\hline \hline & $(1)$ & $(2)$ & $(3)$ & $(4)$ & $(5)$ & $(6)$ \\
\hline Dependent Variable & Ownership & Salary & Ownership & Salary & Ownership & Salary \\
\hline Group 1 & Post-2001 IPO & Top 25\% Employees & Top 10 PE Firm \\
& 0.0363 & -0.1621 & 0.0562 & -0.1016 & 0.0458 & -0.1197 \\
& $(0.0076)$ & $(0.0394)$ & $(0.0103)$ & $(0.0532)$ & $(0.0099)$ & $(0.0512)$ \\
& & & & & \\
Group 2 & & & & & \\
& & & & & \\
& 0.0343 or earlier IPO & Bottom 25\% Firm & Employees & & \\
& $(0.0072)$ & $(0.0371)$ & $(0.0105)$ & $(0.0541)$ & $(0.0062)$ & $(0.0317)$ \\
\hline \hline
\end{tabular}

Each regression is based on the same specification as in column 4 of Tables 3 (odd columns of this table) or 4 (even columns) with the PrivateEquity variable broken into at least two groups. Top 10 PE firm in columns 5 and 6 includes the ten private equity firms on the Power List in the March 5, 2007 issue of Fortune: Blackstone, KKR, Carlyle, TPG, Bain Capital, Providence Equity Partners, Apollo Advisors, Warbarg Pincus, Cerberus, and Thomas H. Lee. Note that Groups 1 and 2 differ at $12 \%$ level in column 2, 19\% significance level in column 3 , and $22 \%$ level in column 4 . 


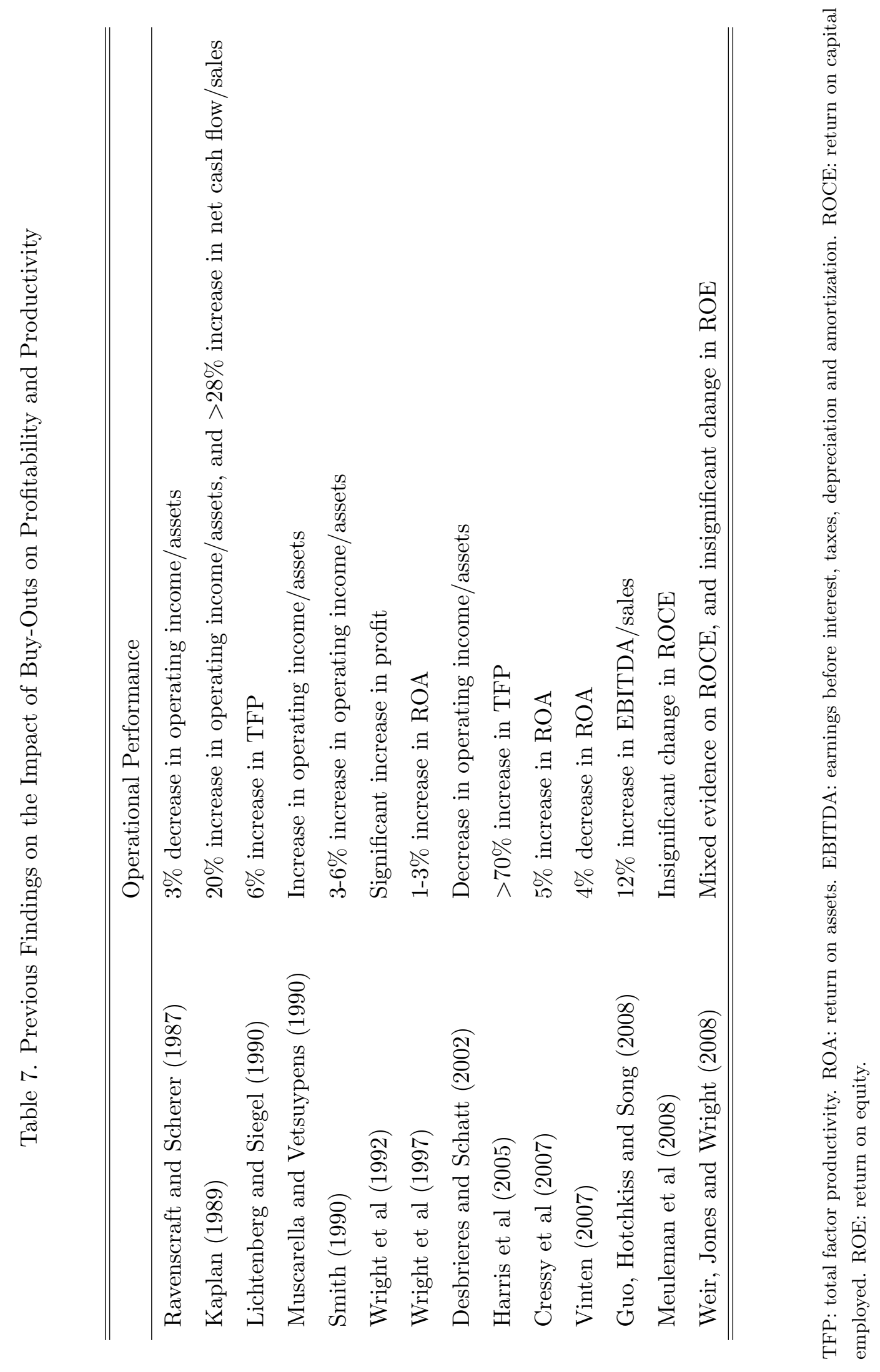


Table 8. Effect of Private Equity on Operational Measures

\begin{tabular}{lccccc}
\hline \hline & $(1)$ & $(2)$ & $(3)$ & $(4)$ & $(5)$ \\
\hline Dependent Variable & Debt/Assets & ROA & EBITDA/Assets & Sales/Emp & Emp/Assets \\
PrivateEquity & 0.5154 & 0.0129 & 0.0156 & 131.80 & -0.0010 \\
& $(0.0199)$ & $(0.0164)$ & $(0.0111)$ & $(68.58)$ & $(0.0017)$ \\
& & & & & \\
GoingPrivate & 0.0349 & 0.0137 & 0.0040 & -61.80 & -0.0012 \\
& $(0.0250)$ & $(0.0206)$ & $(0.0142)$ & $(86.26)$ & $(0.0022)$ \\
\hline$R^{2}$ & 0.3187 & 0.0921 & 0.2378 & 0.1240 & 0.1449 \\
\hline \hline
\end{tabular}

Each regression includes controls similar to those in column 4 of Tables 3 to 5 , except column 4 which excluded controls for sales and employees, and column 5 which excludes the asset control variable. Note: PrivateEquity and GoingPrivate are different at 1\% significance level in column 1, and at the $8 \%$ significance level in column 4 . 
Figure 1: Fraction of Petco Owned by CEO

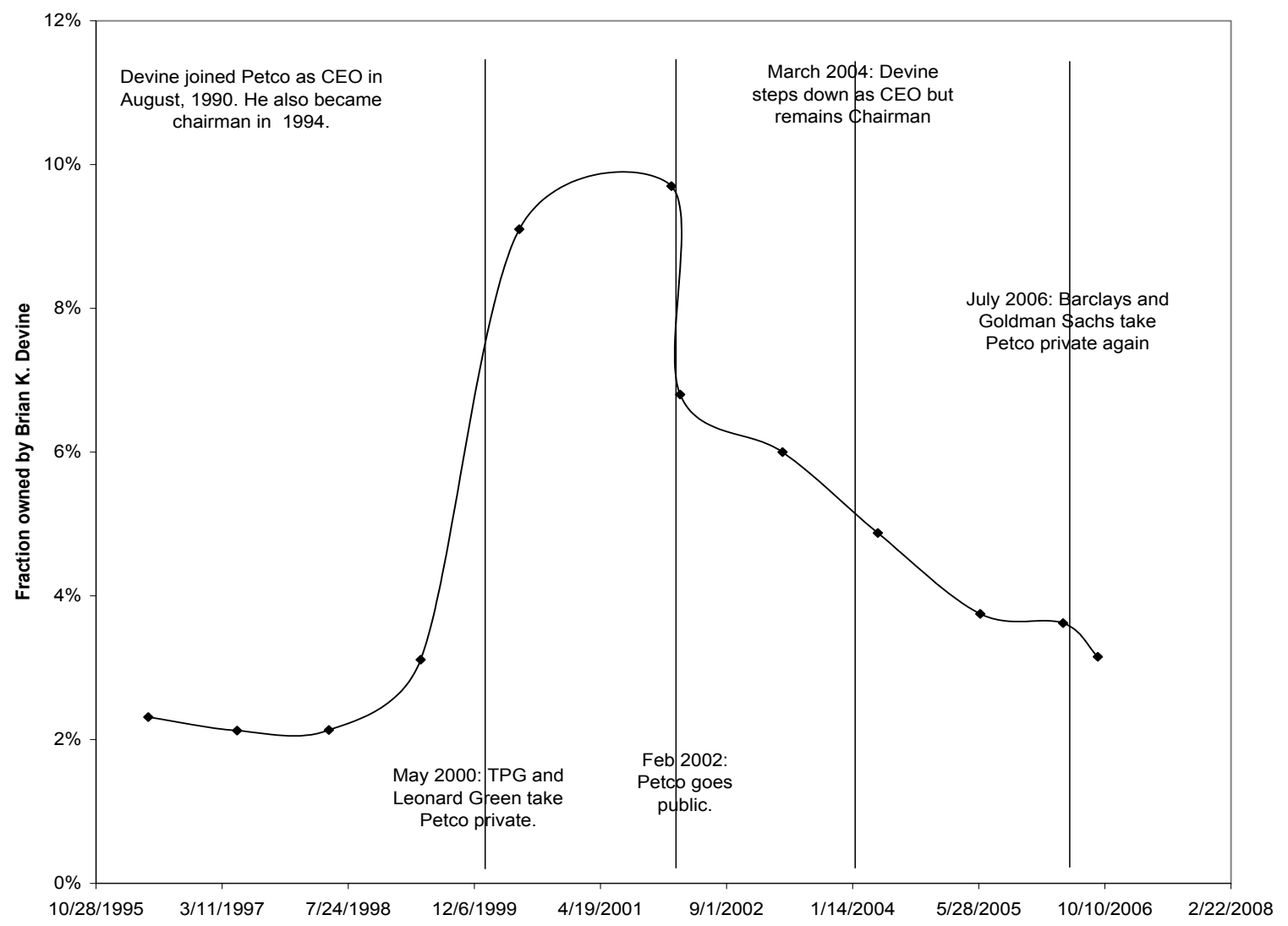


Figure 2: Kernel Densities of Unconditional Distributions of Fraction of Equity Owned by Highest Paid Executive in PE and Public Companies

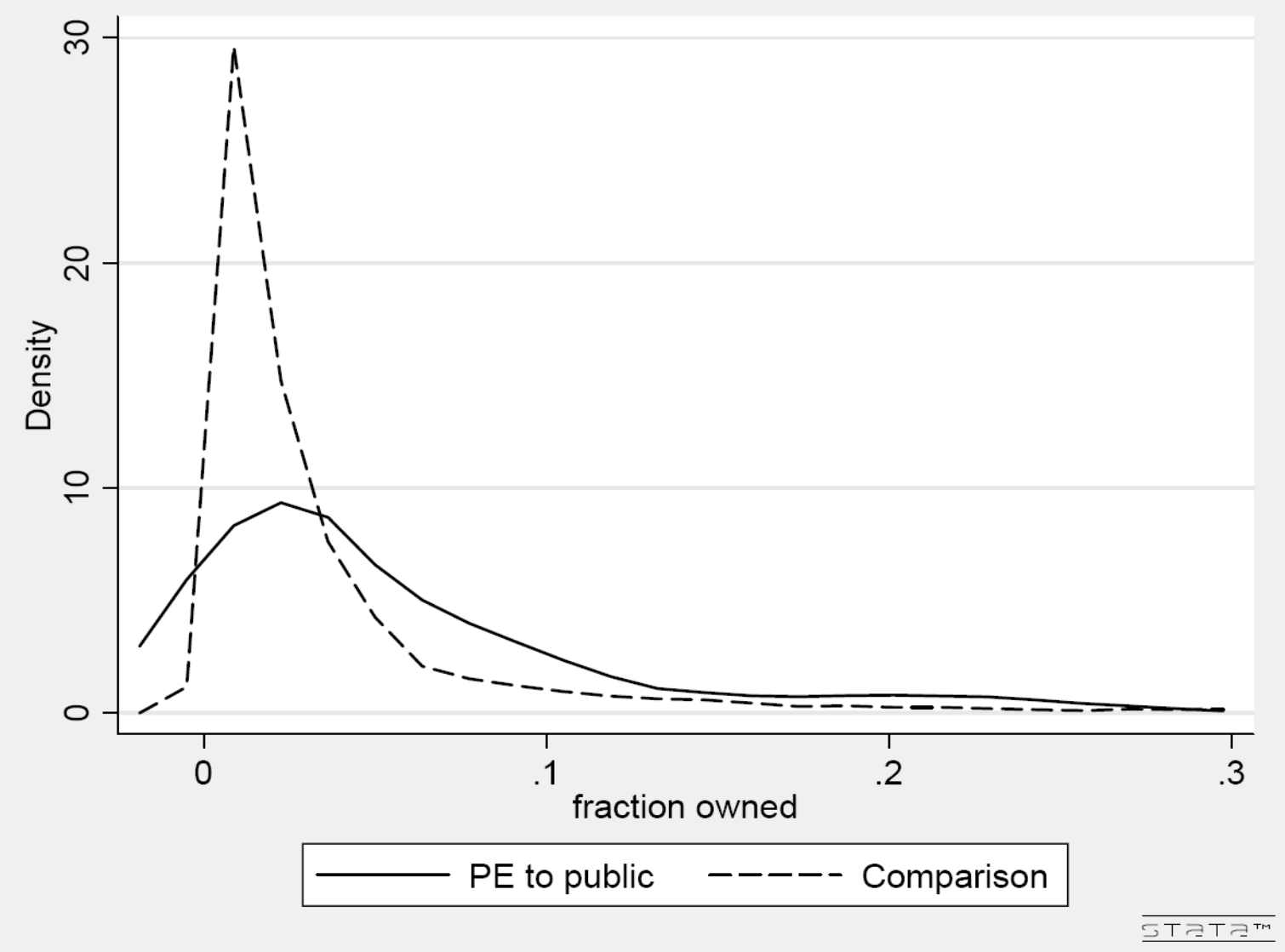


Figure 3: Kernel Densities of Conditional Distributions of Fraction of Equity Owned by Highest Paid Executive in PE and Public Companies

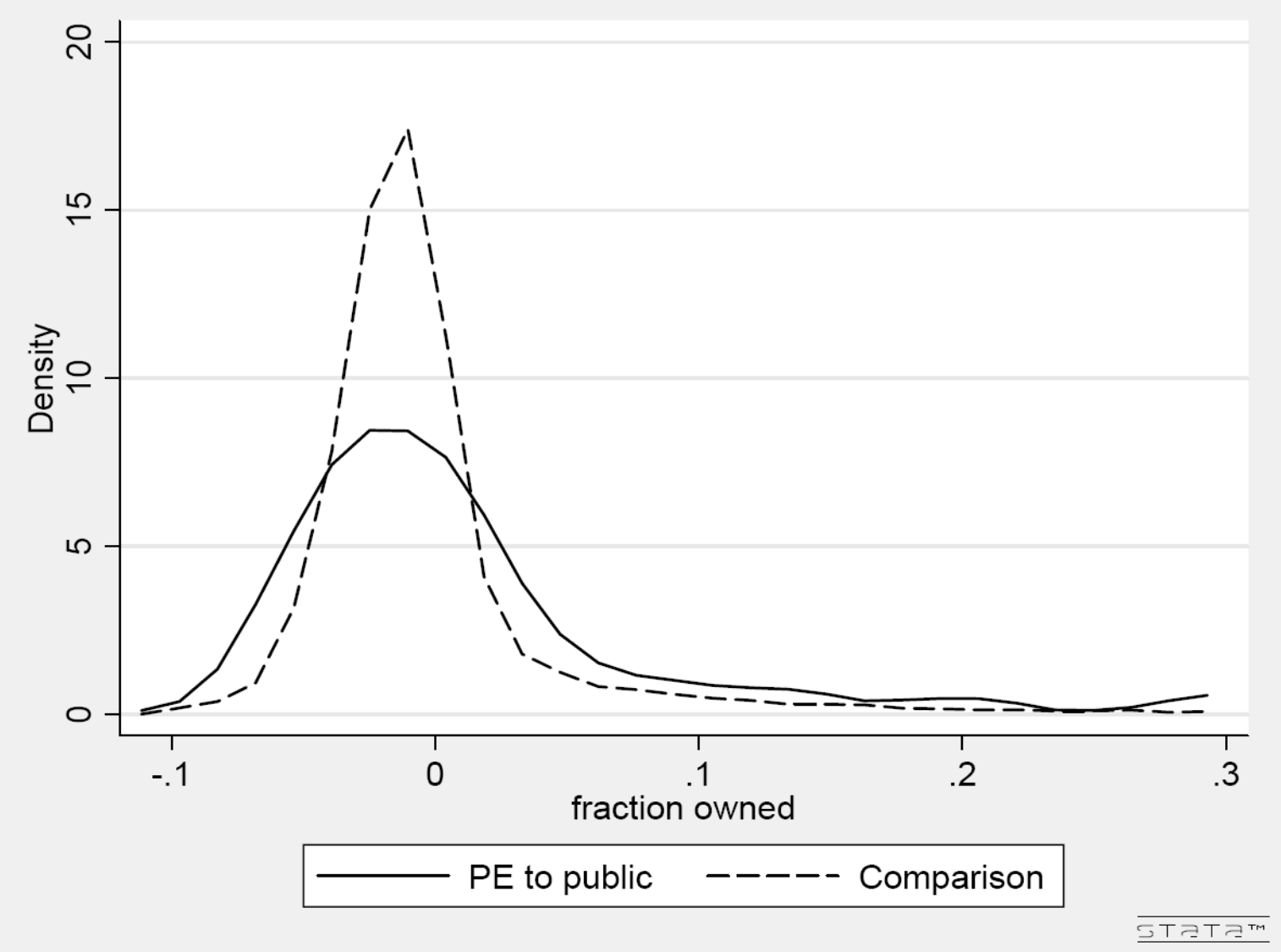

Conditional on same controls as Table 3, column (4). 
Figure 4: Debt-Assets Ratio at Petco

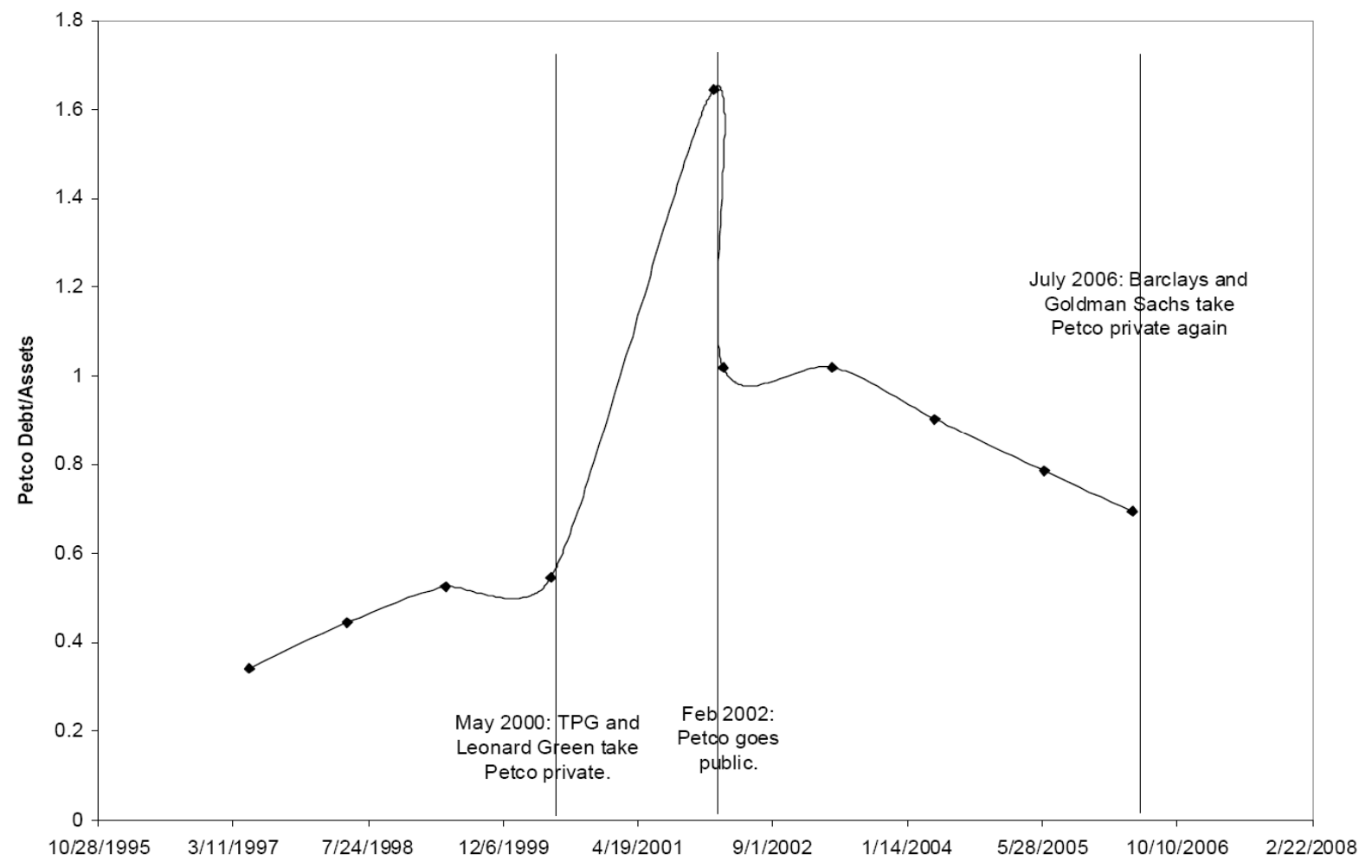


Figure 5: ROA at Petco

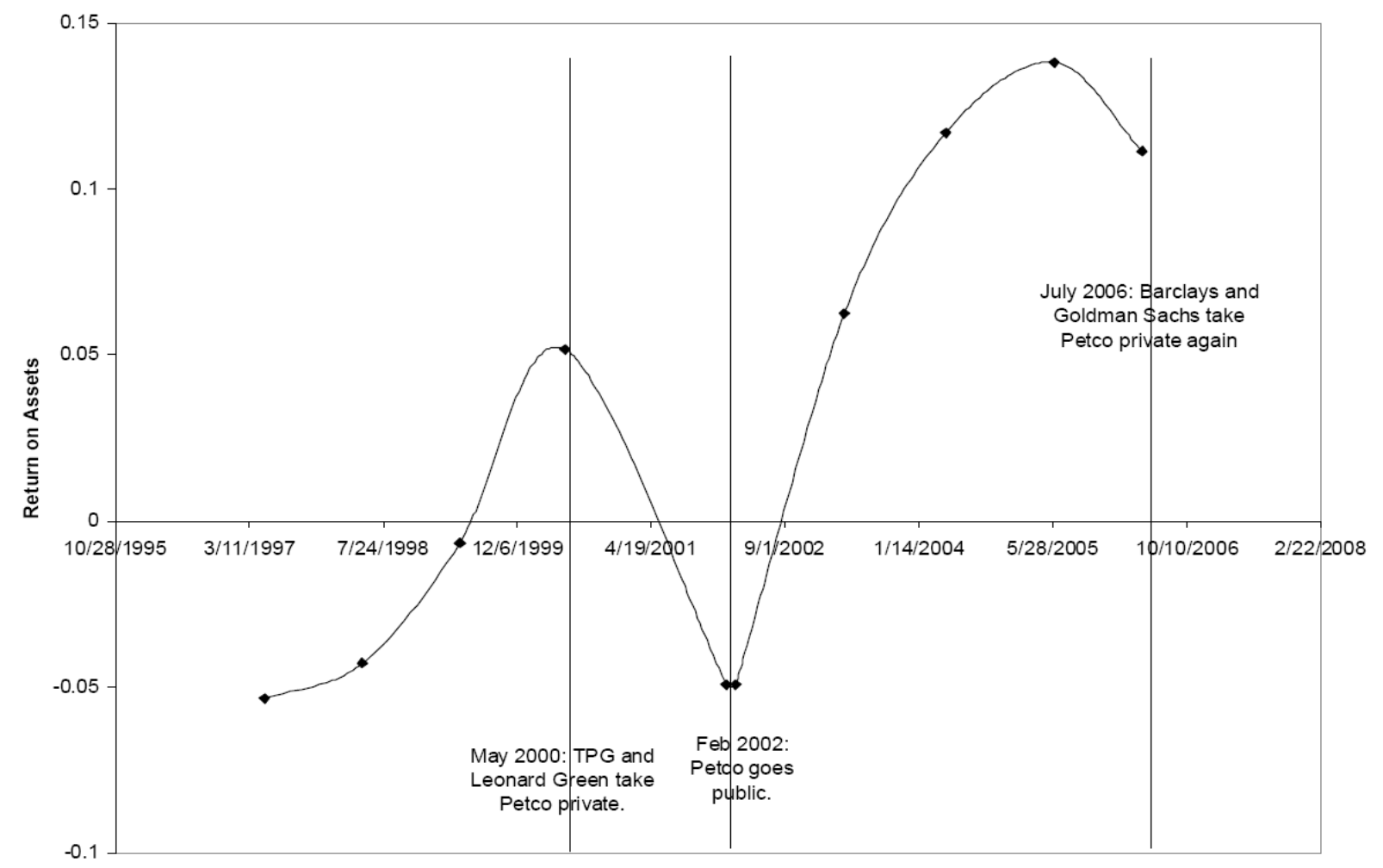


Figure 6: Executive Ownership at PE-Backed Companies

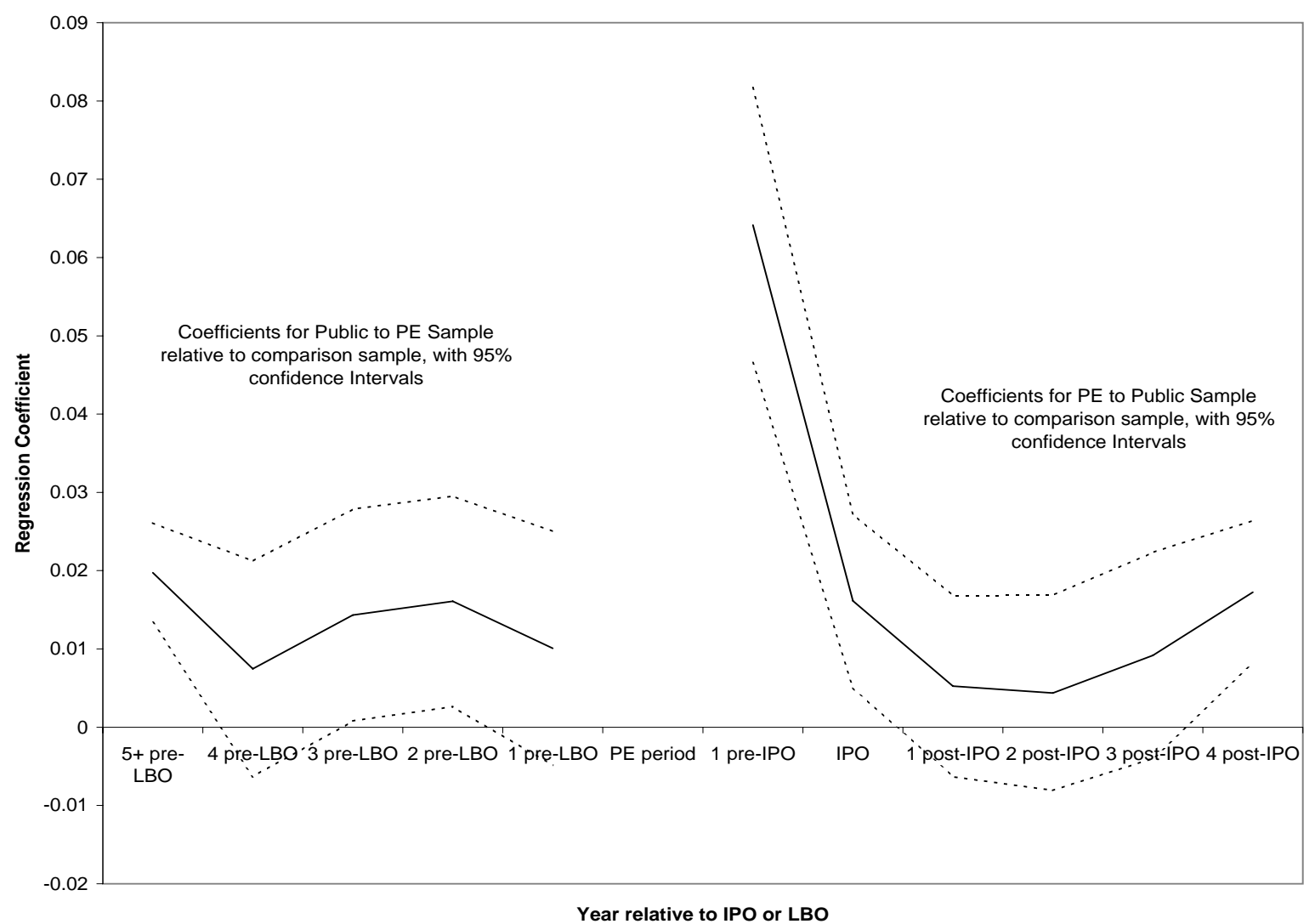


Figure 7: Executive Salary at PE-Backed Companies

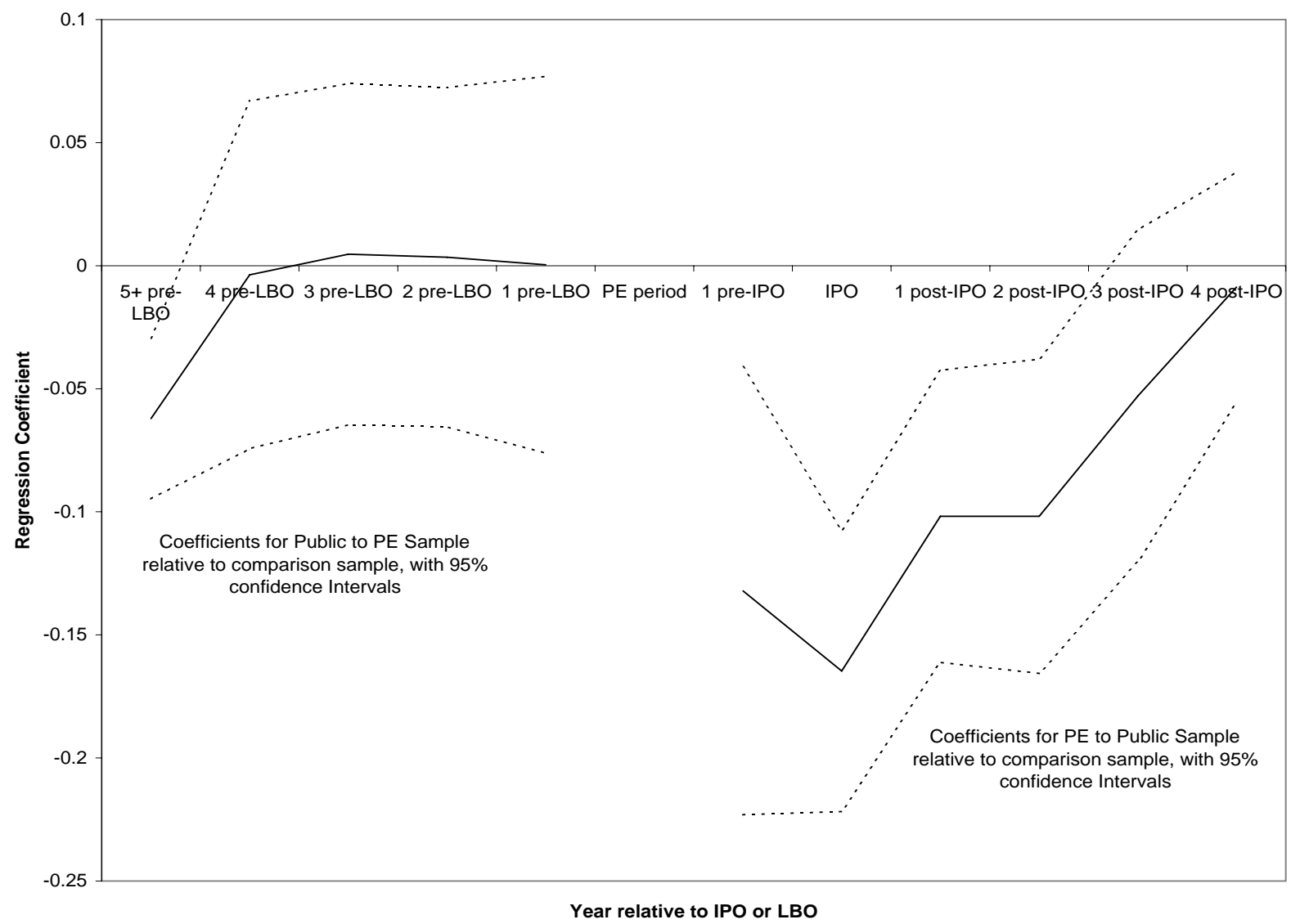


Figure 8: Debt/Assets at PE-Backed Companies

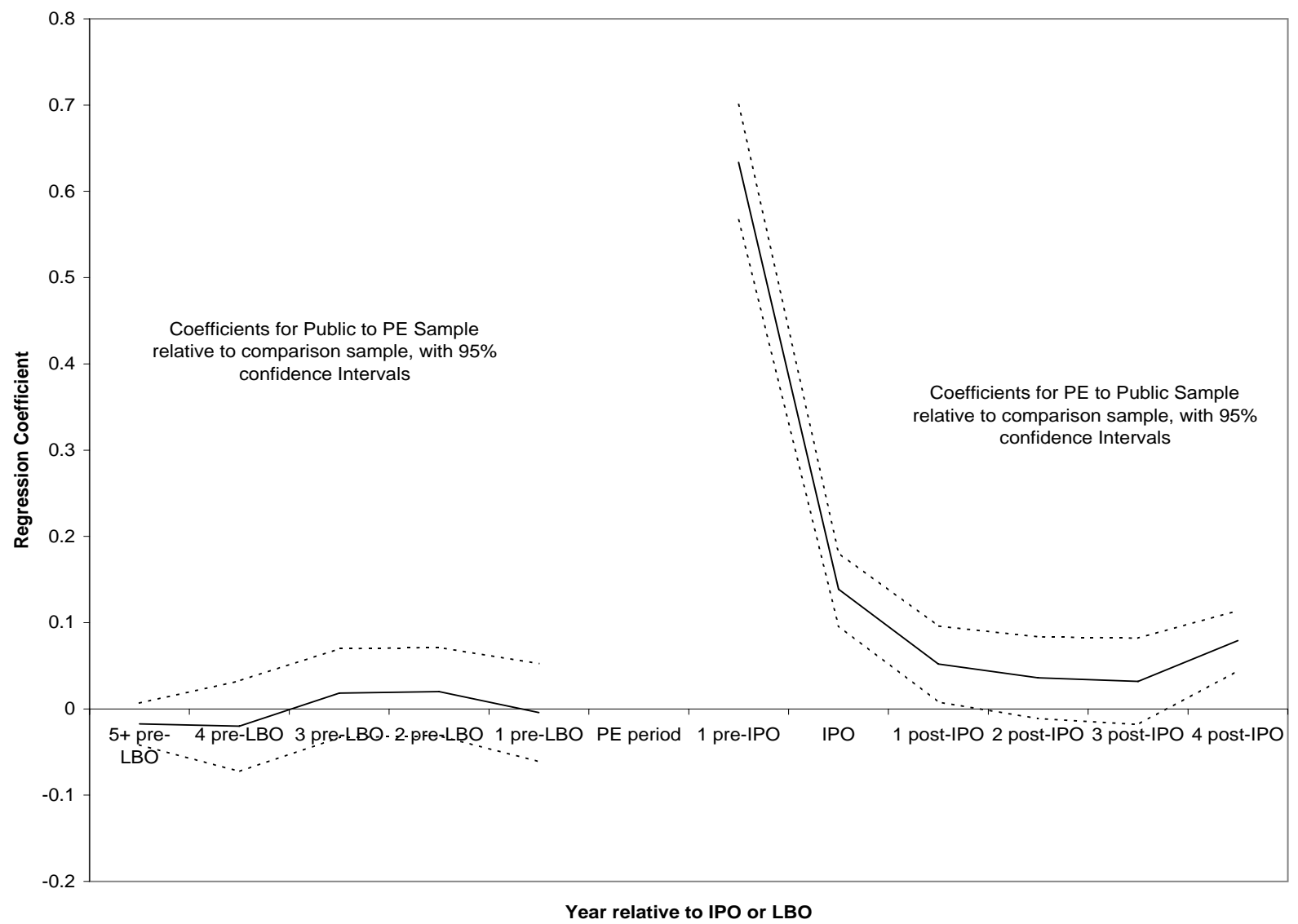


Figure 9: Sales Per Employee at PE-Backed Companies

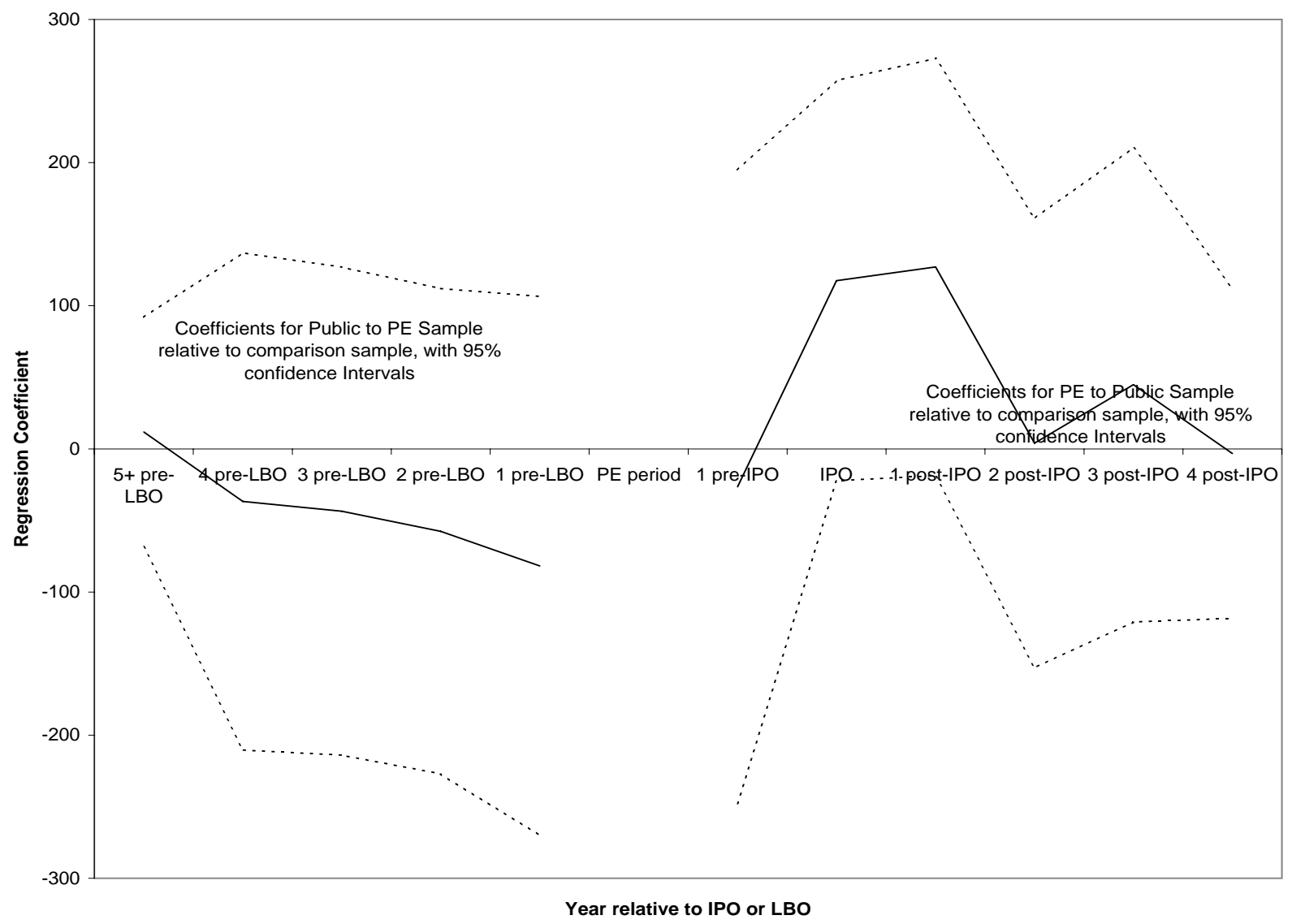

